\title{
Factors Causing Language Loss Experienced by an American Native Speaker in Multilingual Situation in Indonesia
}

\author{
Saptina Retnawati \\ Universitas Pamulang, Banten, Indonesia \\ Email: teena.calissta@gmail.com
}

\begin{abstract}
Bilingualism and multilingualism are common phenomena in language use. Those who are bilinguals or multilingual normally get the language competence because they are living in multilingual area, or in a country which has variety of languages and cultures. Indonesia is one of countries which have this wide diversity in cultures, languages, and religions. Furthermore, Indonesian Ministry of Education created a program called Darmasiswa program which enabled students from abroad to study Bahasa Indonesia and Indonesian cultures. By following this program, those students are learning new language and culture in multilingual situation. One of evidences occurred with a student from America, named Angela who also has multilingual family background. She was exposed to a lot of languages since she was born, and she also studied new languages in Indonesia, as a result she has capability to speak more than two languages. In this kind of situation, the researcher was interested to find out the language loss she might experience during her study. This study aimed to find factors influenced on language loss by her. The approach of this study was qualitative. The researcher applied mixed techniques to obtain data; recording the conversations in natural setting and interview. The analysis was interpretive. The findings of this study found that there were two factors that influenced language loss; internal factors and external factors, which dominated by cultural factor. Also, it happened because of the fact that Bahasa Indonesia is more dominant than her mother tongues.
\end{abstract}

Keywords: Language Loss, Multilingualism, American Native Speaker. 


\section{INTRODUCTION}

Bilingualism and multilingualism are common phenomena in language use. Those who are bilinguals or multilingual normally get the language competence because they are living in multilingual area, or in a country which has variety of languages and cultures. Indonesia is one of countries which have this wide diversity in cultures, languages, and religions. According to the latest survey conducted by the ethnologue community, there are in total 719 languages that are used in Indonesia. From that huge number of languages, Indonesian language (bahasa Indonesia) is used as the official language, and each province has its own traditional language which is used in daily life especially in informal situation. It is concluded that most Indonesians are able to speak at least two languages; Bahasa Indonesia and their native language in each province.

This situation, somehow, are not experienced only by Indonesian people in general, but also some visitors, tourists, diplomats, or even international students who live in Indonesia for long period of time. When people come to a new place which has different language with his/her mother tongue, they tend to learn that language. Likewise the subject of this study, a student of Darmasiswa program who studied Bahasa Indonesia in Semarang State University. She has lived for almost two years in Indonesia and experienced a lot of multilingual situation. She was born and raised in Los Angeles, California in the United States of America and her parents are immigrant from two different countries. Since she was born, she was exposed to many languages as her parents speak different language. Moreover, she also studied Bahasa Indonesia in Darmasiswa program which leads her to study more languages during the program.

According to the Ministry of Education, The Darmasiswa program started in 1974 as a part of ASEAN (Association of South East Asian Nations) initiative, offering students from abroad to study Bahasa Indonesia, Indonesian arts, music and crafts. The participants in this program can choose one of 45 different universities located in different cities in Indonesia. At the State University of Semarang, there were twenty students from some foreign countries who joined this scholarship in the academic year of 2013/2014. They were from Hungary, Scotland, Lithuania, Afghanistan, China,England, Italy, Russia, Peru, Japan, Germany, Denmark, the United States, Vietnam, Portugal, Poland, and Thailand.

Because the purpose of the program is to spread the Indonesian language, all participants are required to take Bahasa Indonesia course. In this course, students are taught bahasa Indonesia starting from the basic level. The course also aimed to improve students ' skills in communicating with Indonesians. Therefore, the course material included Indonesian grammar and conversation. It is hoped that the students would be able to communicate using Bahasa Indonesia inside or outside of the classroom both with Darmasiswa students and Indonesian 
native speakers. Since State University of Semarang is located in Central Java, therefore in this situation, most of students of this program were exposed to speak Indonesian and Javanese. In this context, it can be said that they were in multilingual situation.

Related to multilingualism cases, there have been notions or presumptions that people who can speak more than one language tend to experience language loss. Hayne (2010) mentioned that there are two different levels of language loss; personal or familial level or the entire language may be completely loss especially when the entire language ceases to be spoken at all. Meanwhile, immigrant communities in the United States are one of examples of language loss in personal and familial level. This case is in line with the subject of this research whose parents are immigrant from two different countries.

Related to the factors causing language loss, some experts mentioned that language loss is a result of internal and external factors. Sasse (1992), for example, mentioned that cultural, historical, economic, and political forces are some external factors causing language loss. Furthermore, he concludes that political forces have an effect on how a speech community behaves, especially on how political forces foster negative attitudes towards the minority language. However, he argues that "a key factor in language use is the failure of parents to transmit the language to their children. It is because interrupted transmission leads to a lack of proficiency on the part of the younger generation, who then adopt the majority language as their home language and the language of child-rearing, resulting in the ultimate demise of the minority language.

Moreover, in case study of the Mayan community Mazapa, Garzon (1992) also found that "parents were concerned with their children's ability to be successful in the outside world and believed that teaching the minority language would hinder their children's ability to learn Spanish and do well in school". Furthermore, she said these internal factors were more influential than external factors such as the socioeconomic dominance of the majority language speakers, government policies that encouraged the assimilation of indigenous communities, and the prohibition of the minority language in schools. Meanwhile, different from Garzon, Masruddin (2013), conducted a study entitled"influenced factors towards the language shift phenomenon of Wotunese". This study resulted the factors influence significantly on language shift of Wotunese are age, mobilization, bilingualism and language attitude.

Based on the background of the study and literature review mentioned above, the resercher was interested to find out related factors causing her language loss during her study in Indonesia, therefore the researcher conduct the research entitled "Factors Causing Language Loss Experienced by an American Native Speaker in Multilingual Situation in Indonesia". 


\section{METHOD}

The study employed a descriptive qualitative design which concerned on utterances produced during the conversations by the American student of Darmasiswa program with her colleagues or with Indonesian native speakers. I recorded the conversation in some informal occasions. The spoken conversations were then transcribed into written form so that I could analyze language loss element from conversation in natural setting, and interview. The data were obtained in several steps; observation, audio recording, and interviews. The triangulation process was conducted to ensure the reliability of data analysis.The next step was transferring the spoken data into the written form. I transcribed the data without changing or improving them. The guideline of transcribing the data into written form was used as the standard of transcription.

After being collected, I analyzed the data based on the factors causing language loss. There were two stages in analyzing the data, i.e. data identification and classification and then data tabulation.

\section{RESULTS AND DISCUSSION}

The findings of this study indicate that there were two factors influenced language loss; they were internal factors and external factors. It is found that subject research got language loss because Bahasa Indonesia is more dominant than her mother tongues. There are some factors that cause the occurence of language loss by the research subject in this study. Multilingualism and oppression of using Indonesian language are external factors that results in code-switching, which is then give impact to the loss of language that she has learned before (English, Khmer, Teo Chew, and Spanish). From the interview conducted by the researcher, it can be concluded that she experienced the loss of English capability. As English is the minority language here, she tends to use Indonesian language more than English to communicate in daily life. She confessed that her English is now gone down and that there are some English words that she can not speak anymore, particularly the sophisticated words. She prefer to use basic English vocabularies to communicate with Indonesian native speakers who are able to speak in English, because she follows their ability in English.

Other results from the interview was that she uses more Indonesian tag question, in the end of English sentences. For instance; "You are going to come, ya?". The tag ' $y a$ ' indicates that she follows the Indonesian form of sentence; "Kamu akan datang kesini, ya?" In standard English, she might have used "Are you going to come here?", but she prefer to use Indonesian form of sentence.

The second factor that cause language loss is oppression of using a certain language. As stated by Erin Haynes (2010) who found that education field in U.S has a history of suppressing the active use of non-English languages for 
the purpose of promoting assimilation of the speakers. It is then related to the aim of Darmasiswa program that all the students are expected to communicate with Indonesian language with other speakers in daily life. It results in the habit to speak Bahasa Indonesia more than other languages. Based on the observation and interview, the research subject in this study chooses to speak in Indonesian with Indonesian speakers at the first time they meet. She said that using Indonesian with the native speakers of Indonesia is more comfortable, eventough there might be switch to English or even Javanese to clarify something. This, of course, gives impact to her ability in using English. Based on the data in the transcribed conversations, I found several examples that she often inserted Indonesian words to English sentence in order to keep the conversation with Indonesian speaker flows smoothly.

(1) T3-19

T : "Ya..it's very nice to stay here, I mean--because..."

A : "But you have to rent it or is it like a kost where you just rent aroom?"

T : "A kost."

(Transcription 3, utterance 19)

(1) T1-14

A : "Ya, so confuse. The preposition - I know that sedikit headache. And then I think some (inaudible)."
T : "Aa?"

14)

(3) $\mathrm{T} 2-12$

A : “OK . Because I was trying to a warung over there that I usually go to, and..."

T : "Warung, which one?"

(Transcription 2, utterance 12)

The Indonesian words 'kost' (dormitory), 'sedikit' (a little bit), and 'warung' (small restaurant) are inserted to English sentences. It means that she experienced the loss of English ability to express some words like 'dormitory', 'a little bit', and 'small restaurant.' On the other hand, she gained the Indonesian words 'warung', 'sedikit', and 'kost' and use them more often.

The code switching that are performed in the conversations gives impact to the loss of her English ability. An example was taken when she chatted with her co-worker (an American). She said, "This arrangement mirips mas Nanang's. "She did not realize that she used Indonesian word 'mirips' and she added ' $s$ ' as the singular marker of the subject 'this arrangement'. The use of English form of sentence in Indonesian word indicates that her English language ability is somehow loss.

To sum up, the diagram below explain the sequences of some language phenomena that resulted in language loss by the research subject in this study 


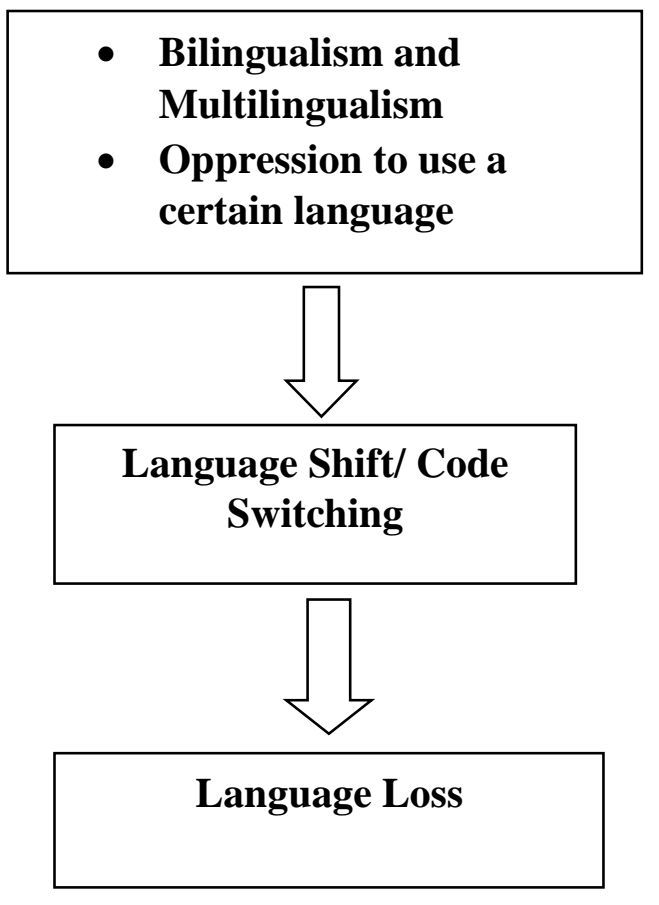

From the diagram of the sequences of language loss phenomenon above, it can be concluded that she experienced code-switching as a result of multilingualism setting in Indonesia and oppression to use Indonesian language in daily life that finally gives impact to the loss of English language capabilites that she has learned before.

\section{REFERENCES}

Sasse, Hans-Jurgen. 1992. Theory of language death. In Mattias Brenzinger (Ed.), Language Death: Factual and Theoretical Explorations with Special Reference to East Africa, 7 - 30. Berlin: Mouton de Gruyter.

Auer, P. 2002. Code-Switching in Conversation: Language, Interaction and Identity.London:Taylor\& Francis eLibrary.

Ariffin, K. and Husin, M. S. 2011. Codeswitching and Code-mixing of English and Bahasa Malaysia in Content-Based Classrooms: Frequency and Attitudes. The Linguistics Journal, Vol. 5 Issue 1.

Cantone, Katja F. 2007. Code-Switching in Bilingual Children. New York: Springer.

Chloros, P. G. 2009. Code-switching. New York: Cambridge University Press.

Crawford, J. 1996. Stabilizing Indigenous Languages: Seven Hypotheses on Language Loss Causes and Cures.Arizona: Northern Arizona University.

Fitriyani, I.D. 2013. Code Switching Used by Students in a Speaking Class Activity (The case of the sixth semester students of English Study Program at Dian Nuswantoro University Semarang in the Academic Year of 2012/2013). Thesis. English 
Language Education Post-graduate

Program Semarang State

University.

Guardado, M. 2002. Loss and Maintenance of First Language Skills: Case Studies of Hispanic Families in Vancouver. Thesis.Vancouver: University of British Columbia.

Gulzar, M. A. 2010. Code-switching: Awareness about Its Utility in Bilingual Classrooms. Bulletin of Education and Research December, Vol. 32, No. 2 pp. 2344. Retrieved 4 October 2013.

Gumperz, J. 1982. Discourse Strategies. New York: Cambridge University Press.

Haynes, Erin. 2010. What is Language Loss? Berkeley: University of California.

Hidayat, T. 2012. An Analysis of Code Switching Used by Facebookers ( Case Study in a Social Network Site). Thesis. English Education Study Program Language and Arts Department of Sekolah Tinggi Keguruan dan Ilmu Pendidikan (STKIP) Siliwangi Bandung. Retrieved on November, 112013.

Hoffmann, C. 1991. An Introduction to Bilingualism. London: Longman Group UK limited.

Marasigan, E. 1983. Code-Switching and Code-Mixing in Multilingual Societies. Singapore: Richard Clay Pte Ltd.
Milroy, L. \& Muysken. 1995.

Introduction: Code-Switching and Bilingualism Research. New York: Cambridge University Press.

Retnawati, Saptina \& Mujiyanto, Yan. 2015. Code switching used in conversations by an american student of the darmasiswa program. Journal of Language and Literature Vol. X, No. 1. Semarang State University.

Suprihartanta F.P. 2012. Code-switching In Science Teachers' Talk: The case of code-switching in the Talk of the Teachers of Biology, Chemistry, Physics and Mathematics of SMAN 1 Slawi. Thesis. English Language Education Postgraduate Program Semarang State University.

Syahdan, Syahdan, Destina Kasriyati, and Refika Andriani. "Analisis Kesopanan Berbahasa terhadap Kemampuan Tindak Tutur Mahasiswa." Lectura: Jurnal Pendidikan 8.2 (2017).

Wardaugh, R. 1998. An Introduction to Sociolinguistics. New York: Brasil Blackwell.

Wardhaugh, R. 2006. An Introduction to Sociolinguistics - Fifth edition. Oxford: Blackwell Publishing Ltd. 